\title{
Nutritional potential and utilization of processed Roselle (Hibiscus sabdariffa L.) seed meal by grazing Red Sokoto bucks in Semi-Arid Nigeria \\ *11Abdurrahaman, S. L., ${ }^{1}$ Muhammad, H. U., ${ }^{1}$ Mustapha, K., ${ }^{1}$ Danyaya, A. I. and \\ ${ }^{2}$ Muhammad, I. R. \\ ${ }^{\prime}$ Department of Animal Science, Federal University Dutse, \\ PMB 7156, Dutse, Jigawa State-Nigeria \\ ${ }^{2}$ Department of Animal Science, Bayero University Kano, \\ PMB 3011 Kano State, Nigeria
}

*Corresponding author: abdurrahaman.s1@fud.edu.ng; +234803 9236296

Abstract

Two studies were conducted to explore the utilization of rosolle seed meal (RSM) as a feedstuff in small ruminant feed. In study one, the effect of processing methods on the proximate compositions, mineral contents and anti-nutritional factors of roselle seed were evaluated. Four different processing methods were evaluated as treatments, $T 1=$ was control (untreated roselle seed), $T 2$ = fermented roselle seed, $T 3=$ hot water treated roselle seed, and $T 4=$ lye water treated roselle seed. The prepared samples were subjected to laboratory analysis. In the second study, feeding trial was conducted to assess the performance of grazing red Sokoto bucks supplemented with diets containing processed roselle seed meals. Four experimental diets were formulated using wheat offal, sorghum husk, rice husk, salt, bone meal and processed RSM $(T 1=$ Untreated RSM; T2 = Fermented RSM; T3 = Hot water treated RSM and T4 = Lye water treated RSM) as treatments. The bucks were supplemented the diets for 84 days, after six hours grazing in a 50 hectares' rangeland daily. Sixteen red sokoto bucks, four bucks per treatment with average weight of $11.69 \pm 0.32 \mathrm{~kg}$ were used in a completely randomized design, water was provided ad libitum. Data were generated on feed intake, weekly weight changes and feed conversion ratio. Results obtained in study one indicated that processing methods had no significant $(P>0.05)$ effect on the proximate compositions of resolle seed except on ether extract and dry matter contents. The mineral compositions of the roselle seed obtained showed that there were significant $(P<0.05)$ differences in the values of Potassium (K), Sodium ( $\mathrm{Na}$ ) and Copper $(\mathrm{Cu})$. Lye water treated roselle seed (T4) was statistically superior to others in terms of $K$ and $N a$, while fermented roselle seed (T2) was statistically superior in $C u$. The result obtained in the analysis of antinutritional factors revealed that all the parameters were significantly $(p<0.05)$ different. The values of tannin, saponin, Pytate, cyanide and oxalate ranged from $0.38-0.87 \mathrm{mg} / \mathrm{g}, 13.21$ $22.57 \mathrm{mg} / \mathrm{g}, 33.13-50.79 \mathrm{mg} / \mathrm{g}, 6.51-10.34 \mathrm{mg} / \mathrm{g}$ and $2.12-4.36 \mathrm{mg} / \mathrm{g}$ respectively. Results from the second study showed that there was significant $(P<0.05)$ difference in the mean values of total weight gain, average feed intake and total feed intake. In conclusion, processing methods substantially reduced the effect of anti-nutritional factors in roselle seed which can serve as a good source of feedstuff for small ruminant production. Also, supplementation of roselle seed meal can significantly improve the performance of goats without any detrimental effect.

Keywords: Nutritive values, Roselle seeds meal, processing, bucks

La Potentiel nutritionnel et L'utilisation de la farine de graines transformée de Roselle (Hibiscus sabdariffa L.) par pâturage des mâles Sokoto rouges dans le zone semi-aride au Nigeria

Résumé

Deux études ont été menees pour explorer l'utilisation de la farine de graines de rosolle lle 


\section{Nutritional potential and utilization of processed Roselle (Hibiscus sabdariffa L.)}

'RSM') comme aliment dans l'alimentation des petits ruminants. Dans la première étude, l'effet des méthodes de traitement sur les compositions immédiates, les teneurs en minéraux et les facteurs anti-nutritionnels de la graine de roselle ont été évalués. Quatre méthodes de traitement différentes ont été évaluées comme traitements, $T 1$ = était témoin (graine de roselle non traitée), $T 2$ = graine de roselle fermentée, $T 3$ = graine de roselle traitée à l'eau chaude et T4 = graine de roselle traitée à l'eau de lessive. Les échantillons préparés ont été soumis à une analyse en laboratoire. Dans la deuxième étude, un essai d'alimentation a été mené pour évaluer les performances des mâles Sokoto rouges au pâturage complétés par des régimes contenant des farines de graines de roselle transformées. Quatre régimes expérimentaux ont été formulés en utilisant des abats de blé, des balles de sorgho, des balles de riz, du sel, de la farine d'os et du 'RSM' transformé (T1 = le 'RSM' non traité ; T2 = le 'RSM' fermenté; $T 3=$ le 'RSM' traité à l'eau chaude et $T 4=$ le 'RSM' traité à l'eau de lessive) comme traitements. Les mâles ont été nourris pendant 84 jours, après six heures de pâturage quotidien dans un pâturage de 50 hectares. Seize mâles sokoto rouges, quatre mâles par traitement avec un poids moyen de 11,69 \pm 0,32 kg ont été utilisés dans une conception complètement aléatoire, de l'eau a été fournie ad libitum. Des données ont été générées sur la consommation alimentaire, les changements de poids hebdomadaires et le taux de conversion alimentaire. Les résultats obtenus dans la première étude ont indiqué que les méthodes de traitement n'avaient pas d'effet significatif $(P>0,05)$ sur les compositions proches de graines de résolle, sauf sur l'extrait d'éther et la teneur en matière sèche. Les compositions minérales de la graine de roselle obtenues ont montré qu'il y avait des différences significatives $(P<0,05)$ dans les valeurs de Potassium (K), Sodium (Na) et Cuivre (Cu). La graine de roselle (T4) traitée à l'eau de lessive était statistiquement supérieure aux autres en termes de $\mathrm{K}$ et de $\mathrm{Na}$, tandis que la graine de roselle fermentée (T2) était statistiquement supérieure en $\mathrm{Cu}$. Le résultat obtenu dans l'analyse des facteurs antinutritionnels a révélé que tous les paramètres étaient significativement différents $(p<0,05)$. Les valeurs de tanin, saponine, pytate, cyanure et oxalate variaient respectivement de 0,38 à $0,87 \mathrm{mg} / \mathrm{g}, 13,21$ à 22,57 mg/g, 33,13 à 50,79 mg/g, 6,51 à 10,34 mg / g et 2,12 à 4,36 mg/ $g$. Les résultats de la deuxième étude ont montré qu'il y avait une différence significative ( $P$ $<0,05)$ dans les valeurs moyennes du gain de poids total, de la prise alimentaire moyenne et de la prise alimentaire totale. En conclusion, les méthodes de transformation ont considérablement réduit l'effet des facteurs anti-nutritionnels dans les graines de roselle qui peuvent servir de bonne source d'alimentation pour la production de petits ruminants. En outre, la supplémentation en farine de graines de roselle peut améliorer considérablement les performances des chèvres sans aucun effet néfaste.

Mots clés: Valeurs nutritives, farine de graines de roselle, transformation, dollars

\section{Introduction}

Available forages do usually contain low energy and protein content and this affects voluntary intake and digestibility leading to loss of weight amongst the animals, as dry season grow longer. In addition, the competition between man and monogastric also stand as a militating factor to the realization of the full potential of small ruminant production (Uguru, 2014; Nyako,
2015; Ogunbosoye et al., 2015). The above prevailing conditions justify efforts towards sourcing for alternative and locally available means of feeding ruminants to increase their productivity while contending with the problem of insufficient conventional feed resources (Ogunbosoye et al., 2015; Abdurrahaman et al., 2017). However, one of the feed ingredients that can be used as protein supplement with little or no cost is Hibiscus sabdariffa (roselle) 
seeds (Maffo et al., 2014). Hibiscus belongs to the Malvaceae family (Sahar et al., 2017), and it is quite large, containing several hundred species that are native to warm-temperate, subtropical and tropical regions throughout the world. Roselle seeds are byproduct that is left behind during processing of roselle products (Nyam et al., 2009). Furthermore, Roselle seeds have been found to contain high amount of protein, dietary fiber, lipids, and minerals (Tounkara et al., 2011). Preliminary studies also show that the raw roselle seed contains $22 \%$ crude protein, $89 \%$ Dry matter, $20 \%$ crude fibre, $21 \%$ lipid and $6.4 \%$ ash content (Maffo et al., 2014). This plant is cultivated in thousands of hectares in Jigawa state but the potential of its seeds in small ruminant production is yet to be explored. However, despite the high nutritional value of this seed, it contains anti nutritional factors such as tannin, saponin, cyanide, oxalate and Pytate. Anti nutritional factors are substances which interfere with feed utilization and affect the health and production of animal or which act to reduce nutrient intake, digestion, absorption and utilization and may produce other adverse effects (Akande and Fabiyi, 2010; Yacout, 2016). But the effect of these anti nutritional factors can be reduced by various processing methods (Maffo et al., 2014). Therefore, this research work was aimed at providing information on the best processing method in reducing the effects of anti nutritional factors found in the roselle seed for small ruminants' production.

\section{Materials and methods Experimental area}

The study was conducted at Federal University Dutse Teaching and Research Farm. Dutse is the capital city of Jigawa State. The site is located latitude $11^{0} \mathrm{~N} 13^{\circ} \mathrm{N}$ and longitudes $8^{\circ} \mathrm{E} 10^{\circ} 35^{\prime} \mathrm{E}$, at an altitude of $485 \mathrm{~m}$ above sea level. Jigawa state has an estimated land size of 23,154 $\mathrm{km}^{2}$ (Google Earth, 2012). The state is situated within the Sudan Savannah vegetation zone, but there are traces of Guinea savannah in the southern part of the state. The regions are characterized by a long dry season of 7-8 months. The region is characterized by mean annual rainfall ranges from 600 to $1000 \mathrm{~mm}$ with a peak in August. The average minimum and maximum temperature and relative humidity ranges are 12 and $40^{\circ} \mathrm{C}, 40$ and $78 \%$ respectively. Lowest temperatures occur during the harmattan (November - February) and highest from March to June (Olofin, 2008).

\section{Experimental materials}

The Roselle seed that was used in the research was collected from federal university Dutse teaching and research farm. The collected seeds were cleaned by winnowing and hand picking of stones and debris. The cleaned Roselle seeds were subjected to four processing methods: Untreated Roselle seed (control) $\left(\mathrm{T}_{1}\right)$, Fermented Roselle seed $\left(\mathrm{T}_{2}\right)$, Hot water treatment Roselle seed $\left(\mathrm{T}_{3}\right)$, Lye treatment Roselle seed $\left(\mathrm{T}_{4}\right)$.

\section{Processing methods of Roselle seeds Fermentation}

Roselle seed was placed in a muslin cloth and soaked in clean water completely for 3 days under air-tight condition. The water was drained on the $3^{\text {rd }}$ day and the fermented seed was sun-dried as described by Ari et al. (2012a). The Fermented Roselle seed represents treatment $\mathrm{T}_{2}$.

\section{Hot water treatment}

The method adopted by Ari et al. (2012b) was used. The cleaned seeds were poured into aluminum tower pot containing 1 liter of clean water in a batch of $1 \mathrm{Kg}$. The Roselle seeds sample was allowed to boil at $100^{\circ} \mathrm{C}$ for 20 minutes before cooling by spreading on jute bags until stable weight was attained at room temperature. The parboiled Roselle seed represents treatment $\mathrm{T}_{3}$. 
Nutritional potential and utilization of processed Roselle (Hibiscus sabdariffa L.)

\section{Lye treatment}

Lye water was prepared by passing water over gray ash in a barrel. The ash was sieved to remove pieces of charcoal and other impurities. The sieved ash was then placed (without compaction) in a plastic container with holes plugged with sieved cloth at the base of the plastic. Hot water was poured on the ash and a brown liquid dripped at base of the container. This brown liquid represents the lye water that was used in this study. Roselle seed was placed in a muslin cloth and then soaked in the lye for $18 \mathrm{hrs}$. It was removed and then sun-dried for 7days (Akande et al., 2011). This sample represents treatment $\mathrm{T}_{4}$.

\section{Laboratory analysis}

\section{Determination of proximate composition}

Samples of the roselle seeds, differently processed roselle seeds and experimental supplements were collected for proximate analysis. Dry matter, crude protein, crude fibre, ether extract, Nitrogen free extract and ash, were analyzed according to AOAC (2013).

\section{Determination of mineral composition}

Atomic Absorption Spectrometer was used to determine the content of the macro minerals of the Roselle seed such as Calcium $(\mathrm{Ca})$, magnesium $(\mathrm{Mg})$, potassium $(\mathrm{K})$ and sodium $(\mathrm{Na})$, while dietary micro minerals iron $(\mathrm{Fe})$, copper $(\mathrm{Cu})$, zinc $(\mathrm{Zn})$ and manganese $(\mathrm{Mn})$ were determine according to the procedures described by AOAC (2013).

\section{Determination of anti-nutritional factors}

The presence of anti-nutritional factors, Tannin, Oxalates and Cyanide were determined according to AOAC (2013), Phytate according to Stewart (1974) and Saponin according to Peng et al. (1995).

\section{Feeding and management of animals}

A total of sixteen red sokoto bucks with average weight of $11.69 \pm 0.32 \mathrm{~kg}$ were used to evaluate feed intake and growth performance in this study. Prior to the commencement of the experiment, the pens were thoroughly washed with detergent and disinfectant. The animals were dewormed with albendazole $(2 \mathrm{ml} / 10 \mathrm{~kg}$ body weight) and were given tetracycline long active (TLA) antibiotic injection at $(1 \mathrm{ml} / 10 \mathrm{~kg}$ body weight) against bacterial infections. While ecto-parasites was checked using Ivermectin (Ivomec) at $(1 \mathrm{ml} / 50 \mathrm{~kg}$ body weight). The animals were allotted to four (4) dietary treatments with four (4) animals per treatment, in a Completely Randomized Design. The animals were housed individually in an open-sided, wellventilated pens and each pen was equipped with feed and water troughs. The animals were moved for grazing in a 50 hectares' rangeland of the University farm from $8.00 \mathrm{am}$ to $1.00 \mathrm{pm}$ and returned for watering and rest. They were then moved out from $3.00 \mathrm{pm}$ to $5.00 \mathrm{pm}$. While returning from second grazing, the experimental animals were sent to their individual pens and supplement was offered to them according to treatment allocated. Equally, they spent the night in their individual pen.

Animals were fed supplement diet, at $2 \%$ of their body weights. The treatments that were evaluated are $\mathrm{T}_{1}=$ diet containing untreated Roselle seed meal (control), $\mathrm{T}_{2}=$ diet containing fermented Roselle seed meal, $\mathrm{T}_{3}$ $=$ diet containing hot water treated Roselle seed meal and $\mathrm{T}_{4}=$ diet containing lye water treated Roselle seed meal. Clean drinking water was provided to the animals' daily ad libitum. The experiment lasted 84 days after 7 days adjustment period.

\section{Statistical analysis}

The data generated from these studies were analyzed using One-way Analysis of Variance (ANOVA), Procedure of Statistical Analytical system (SAS, 2013). Significant treatment means were separated using least significant difference (LSD) at $5 \%$ level of significance. 
Abdurrahaman, Muhammad, Mustapha, Danyaya, and Muhammad

Table 1: Experimental diets

\begin{tabular}{|c|c|c|c|c|}
\hline \multirow[b]{2}{*}{ Ingredients (\%) } & \multicolumn{4}{|c|}{$\begin{array}{l}\text { Treatments: Roselle Seed Meal Processed by Different } \\
\text { Methods }\end{array}$} \\
\hline & T1 & $\mathrm{T} 2$ & T3 & T4 \\
\hline Processed Roselle seed meal & 35.60 & 35.60 & 35.60 & 35.60 \\
\hline Wheat offal & 13.65 & 13.65 & 13.65 & 13.65 \\
\hline Sorghum husk & 20.00 & 20.00 & 20.00 & 20.00 \\
\hline Rice husk & 30.00 & 30.00 & 30.00 & 30.00 \\
\hline Common salt & 0.25 & 0.25 & 0.25 & 0.25 \\
\hline Bone meal & 0.5 & 0.5 & 0.5 & 0.5 \\
\hline Total & 100 & 100 & 100 & 100 \\
\hline \multicolumn{5}{|l|}{ Calculated analysis } \\
\hline Crude Protein & 15.00 & 15.00 & 15.00 & 15.00 \\
\hline
\end{tabular}

Results

Effect of processing methods on proximate composition of the processed roselle seed meal

The results of proximate compositions of the processed roselle seed meals were presented in Table 2. It shows no significant $(\mathrm{P}>0.05)$ different among the treatments on parameters evaluated except for $\% \mathrm{DM}$ and ether extract. The values of $\%$ DM obtained range from $95.72 \%$ in $\mathrm{T} 2$ to $96.72 \%$ in $\mathrm{T} 1$. $\%$ EE obtained in T3 (4.10\%) was statistically superior $(\mathrm{P}<0.05)$ to other treatments.

Effect of processing methods on antinutritional factors in the roselle seed

Table 3 shows the anti-nutritional factors of the processed roselle seeds. It reveals that all the anti-nutritional factors anlyzed were significantly $(\mathrm{p}<0.05)$ different across the treatments. The value of tannin obtained in this study ranges from $0.38 \mathrm{mg} / \mathrm{g}$ in $\mathrm{T} 3$ to $0.87 \mathrm{mg} / \mathrm{g}$ in $\mathrm{T} 1$. The value of saponin obtained in this study ranges from $13.21 \mathrm{mg} / \mathrm{g}$ in $\mathrm{T} 4$ to $22.57 \mathrm{mg} / \mathrm{g}$ in T1. The pytate obtained in this study ranges from $33.13 \mathrm{mg} / \mathrm{g}$ in $\mathrm{T} 3$ to $50.79 \mathrm{mg} / \mathrm{g}$ in $\mathrm{T} 1$. Cynide obtained in the PRS ranges from $6.51 \mathrm{mg} / \mathrm{g}$ in $\mathrm{T} 2$ to $10.34 \mathrm{mg} / \mathrm{g}$ in T4. The value of oxalate obtained here ranges from $2.12 \mathrm{mg} / \mathrm{g}$ in $\mathrm{T} 1$ to $4.36 \mathrm{mg} / \mathrm{g}$ in T4.

Effect of processing methods on some mineral composition of roselle seed

Table 4 shows the mineral composition of various processed roselle seed. The result of this study indicates that among the macro minerals analyzed, potassium $(\mathrm{K})$ and sodium (Na) were found to be significantly $(\mathrm{p}<0.05)$ different across the treatments. However, Copper $(\mathrm{Cu})$ was found to be significantly $(p<0.05)$ different among the micro minerals. All other minerals analyzed apart from those mentioned above were not significantly ( $p>0.05)$ different among the treatment groups. The values of $\mathrm{K}$ ranges from $639.85 \mathrm{ppm}$ in $\mathrm{T} 1$ to $773.92 \mathrm{ppm}$ in $\mathrm{T} 4$. The value of $\mathrm{Na}$ analyzed in this study ranges from $120.61 \mathrm{ppm}$ in T2 to $160.80 \mathrm{ppm}$ $\mathrm{T} 4$. The value of $\mathrm{Cu}$ ranges from $13.63 \mathrm{ppm}$ in $\mathrm{T} 4$ to $44.27 \mathrm{ppm}$ in $\mathrm{T} 2$. The value of calcium obtained in this study ranges from $500.50 \mathrm{ppm}$ in $\mathrm{T} 2$ to $651.50 \mathrm{ppm}$ in $\mathrm{T} 3$ and T4. $\mathrm{Mg}$ value obtained ranges from $254.90 \mathrm{ppm}$ in $\mathrm{T} 1$ and $\mathrm{T} 4$ to $352.94 \mathrm{ppm}$ in T3. The value of $\mathrm{Zn}$ anlyzed was $7.49 \mathrm{ppm}$ across all the treatments. Mn was found in the range of $12.26 \mathrm{ppm}$ in $\mathrm{T} 1$ to $18.95 \mathrm{ppm}$ in $\mathrm{T} 2$ and $\mathrm{T} 3$.

Effect of processing methods on feed intake and growth performance of grazing red sokoto bucks

Results from feed intake and growth performance of grazing red Sokoto bucks supplemented with diets containing PRSM presented in Table 5, reveals that there was significant $(\mathrm{P}<0.05)$ difference in values of total weight gain, average feed intake and total feed intake. However, there was no significant $(p>0.05)$ different in values of final weight gain and FCR. 
Nutritional potential and utilization of processed Roselle (Hibiscus sabdariffa L.)

Table 2: Proximate compositions of various processed Hibiscus sabdariffa L. seeds

\begin{tabular}{lcccccc}
\hline Parameter (\%) & T1 & T2 & T3 & T4 & SEM & LOS \\
\hline DM & $96.72^{\mathrm{a}}$ & $95.72^{\mathrm{b}}$ & $95.78^{\mathrm{b}}$ & $96.02^{\mathrm{ab}}$ & 0.13 & $*$ \\
CP & 21.16 & 20.83 & 21.00 & 19.07 & 0.63 & $\mathrm{NS}$ \\
CF & 21.44 & 22.21 & 23.73 & 22.61 & 0.58 & NS \\
NFE & 49.67 & 48.86 & 46.97 & 49.91 & 0.97 & NS \\
EE & $3.30^{\mathrm{b}}$ & $3.53^{\mathrm{ab}}$ & $4.10^{\mathrm{a}}$ & $3.67^{\mathrm{ab}}$ & 0.18 & $*$ \\
ASH & 4.43 & 4.57 & 4.23 & 4.75 & 0.11 & $\mathrm{NS}$ \\
\hline
\end{tabular}

DM-Dry matter, CP-Crude protein, CF -Crude fibre, EE-Ether extract NFE-Nitrogen free extract, SEM -

Standard Error of means, LOS-Level of significance, ${ }^{*}$-Significant, NS- not significant.

Table 3: Anti Nutritional factors of various processed Roselle (Hibiscus sabdariffa) seeds

\begin{tabular}{lcccccc}
\hline Parameter $(\mathbf{M g} / \mathbf{g})$ & T1 & T2 & T3 & T4 & SEM & LOS \\
\hline Tannin & $0.87^{\mathrm{a}}$ & $0.63^{\mathrm{b}}$ & $0.38^{\mathrm{c}}$ & $0.42^{\mathrm{c}}$ & 0.06 & $*$ \\
Saponin & $22.57^{\mathrm{a}}$ & $20.53^{\mathrm{b}}$ & $19.85^{\mathrm{b}}$ & $13.21^{\mathrm{c}}$ & 1.07 & $*$ \\
Pytate & $50.79^{\mathrm{a}}$ & $46.22^{\mathrm{b}}$ & $33.13^{\mathrm{d}}$ & $39.69^{\mathrm{c}}$ & 2.01 & $*$ \\
Cyanide & $7.06^{\mathrm{c}}$ & $6.51^{\mathrm{d}}$ & $8.41^{\mathrm{b}}$ & $10.34^{\mathrm{a}}$ & 0.45 & $*$ \\
Oxalate & $2.27^{\mathrm{b}}$ & $4.25^{\mathrm{a}}$ & $2.12^{\mathrm{b}}$ & $4.36^{\mathrm{a}}$ & 0.32 & $*$ \\
\hline
\end{tabular}

SEM- Standard Error of means, LOS-Level of significance, ${ }^{*}$-Significant.

Table 4: Some macro and micro mineral composition of various processed Roselle

(Hibiscus sabdariffa) seeds

\begin{tabular}{lcccccl} 
Minerals (ppm) & T1 & T2 & T3 & T4 & SEM & LOS \\
\hline Macro & & & & & & \\
$\mathrm{Ca}$ & 606.1 & 500.0 & 651.5 & 651.5 & 45.84 & NS \\
$\mathrm{Mg}$ & 254.90 & 274.51 & 352.94 & 254.90 & 27.89 & NS \\
$\mathrm{K}$ & 639.85 & 645.95 & 749.54 & 773.92 & 22.33 & $*$ \\
$\mathrm{Na}$ & 140.70 & 120.61 & 140.70 & 160.80 & 6.43 & $*$ \\
Micro & & & & & & \\
$\mathrm{Zn}$ & 7.49 & 7.49 & 7.49 & 7.49 & 0.92 & $\mathrm{NS}$ \\
$\mathrm{Mn}$ & 12.26 & 18.95 & 18.95 & 17.83 & 1.33 & $\mathrm{NS}$ \\
$\mathrm{Cu}$ & 30.30 & 44.27 & 36.36 & 13.63 & 4.19 & $*$ \\
\hline
\end{tabular}

SEM- Standard Error of means, LOS -Level of significance, *-Significant, Ca-Calcium, Mg-magnesium, K-Potassium, Na- sodium, Zn-Zinc, Mn-manganese, Cu-Copper.

Table 5: Feed intake and growth performance of Red Sokoto Bucks fed Roselle seed meal

\begin{tabular}{lcccccc}
\hline Parameter & $\mathbf{T}_{\mathbf{1}}$ & $\mathbf{T}_{\mathbf{2}}$ & $\mathbf{T}_{\mathbf{3}}$ & $\mathbf{T}_{4}$ & $\mathbf{S E M}$ & $\mathbf{L O S}$ \\
\hline Initial body weight $(\mathrm{kg})$ & 12.03 & 11.06 & 11.66 & 12.00 & 0.32 & NS \\
Final weight $(\mathrm{kg})$ & 13.90 & 14.10 & 14.33 & 14.53 & 0.41 & NS \\
Total weight gain $(\mathrm{kg})$ & $1.87^{\mathrm{c}}$ & $3.04^{\mathrm{a}}$ & $2.67^{\mathrm{b}}$ & $2.53^{\mathrm{b}}$ & 0.29 & $*$ \\
Average feed intake $(\mathrm{kg})$ & $1.27^{\mathrm{b}}$ & $1.42^{\mathrm{a}}$ & $1.50^{\mathrm{a}}$ & $1.47^{\mathrm{a}}$ & 0.05 & $*$ \\
Total Feed intake $(\mathrm{kg})$ & $10.19^{\mathrm{c}}$ & $11.32^{\mathrm{b}}$ & $11.95^{\mathrm{a}}$ & $11.75^{\mathrm{a}}$ & 0.38 & $*$ \\
Feed conversion ratio & 5.91 & 3.40 & 4.01 & 4.99 & 0.42 & NS \\
\hline
\end{tabular}

$\mathrm{T}_{1}=$ diet conta ining untreated Roselle seed meal (control), $\mathrm{T}_{2}=$ diet containing fermented Roselle seed meal, $\mathrm{T}_{3}=$ diet containing hot water treated Roselle seed meal and $\mathrm{T}_{4}=$ diet containing lye water treated Roselle seed meal, Means with different superscript within the same row differed significantly at $\mathrm{P}<0.05$, $\mathrm{SEM}=$ standard error mean, LOS-Level of significance, ${ }^{*}$-Significant, NS- not significant 


\section{Discussion \\ Proximate composition of the processed roselle seed}

The dry matter contents of the seed obtained in this study $(95.72 \%$ to $96.72 \%)$ agreed with $94.34 \%$ for pre-treated roselle seed flour reported by Karma and Chavan (2017) and $(95 \%)$ dry matter reported by Mariod et al. (2013). Lye water treatment (T4) has slightly reduced the crude protein content of the seed to $(19.07 \% \mathrm{CP})$ which implies that lye water treatment has negative effect on protein. With the exception of T4, all other crude protein obtain in the current study were in agreement to those reported by Mariod et al. (2013) for RSM subjected to different treatments; but lower than $(27.78 \%)$ reported by previous researchers (Nzikou et al., 2011). The ether extract was slightly increased in T3 compared to other treatments which indicates that hot water has a positive effect on EE. In the present study, the EE contents ( 3.30 to $4.10 \%$ ) were found to be lower than $(21.85 \%)$ as reported by Nzikou et al. (2011). The crude fibre ( 21.44 to $23.73 \%$ ) and ash (4.23 to 4.75 ) recorded in this study were similar to those reported by Maffo et al., (2014). NFE of the seed was higher than the values $(27.27 \%$, $27.80 \%$ and $13.87 \%$ ) earlier reported by Nzikou et al. (2011); Mariod et al. (2013) and Karma and Chavan (2017), respectively.

\section{Anti-nutritional factors of various processed roselle seed}

Anti-nutritional factors (ANF) are natural agents in feed that limits the bioavailability of nutrients (Kumar et al., 2017). The ANFs analyzed in this research were tannin, saponin, Pytate, cyanide and oxalate. It was observed that hot water treatment (T3) reduced the different anti-nutritional factors more than other treatments. Tannin was significantly reduced by Hot water treatment as compared to other treatments. The tannin contents of the seed obtained in this study was similar to $(0.16 \mathrm{mg} / \mathrm{g})$ reported by Anhwange (2006) but statistically inferior than (17\%) extracted from dried calyces of Hibiscus sabdariffa using solvent extraction method by Okereke et al., (2015). According to Ramchadra et al. (2019), more than 4\% concentration of tannin has been reported to be harmful to ruminants. Condensed tannins have more profound digestibilityreducing effect than hydrolysable tannins, whereas, the latter may cause varied toxic manifestations due to hydrolysis in rumen (Akande et al., 2010; Smitha Patel. et al., 2013). In the present study, saponin contents of the seed ranged from 13.21$22.57 \mathrm{mg} / \mathrm{g}$. The various treatments that were carried out in this study has slightly reduce the saponin content of the roselle seed with lye water treatment (T4) having the highest effect $(13.21 \mathrm{mg} / \mathrm{g})$ as for other treatments. Apart from T4 that was lower than the earlier findings $(2.2 \%)$ tannin contents, all other treatments were similar to the report Anhwange et al., (2006). High concentration of saponin in feed reduces the bioavailability of nutrients; decreases enzyme activity, affects protein digestibility by inhibiting various digestive enzymes such as trypsin and chymotrypsin (Liener 2003; Gemede et al., 2014). However, despite the negative effect of saponin in diet of animals, it also has some beneficial effects of biological importance as antibacterial and anti-protozoal (Avato et al., 2006; Kumar et al., 2017). Phytate content of the seed was highly reduced to $33.13 \mathrm{mg} / \mathrm{g}$ in hot water treatment (T3) which implies that T4 was more effective compared to other treatments, but all values of phytate obtained in the current work were much higher than $(2.58 \mathrm{mg} / \mathrm{g}$ and $5.90 \mathrm{mg} / 100 \mathrm{~g}$ ) reported Karma and Chavan (2017) and Anhwange et al. (2006). Phytate works as a highly negatively charged ion and its presence in the diet has a negative impact on the bioavailability of divalent and trivalent mineral ions in non ruminants 


\section{Nutritional potential and utilization of processed Roselle (Hibiscus sabdariffa L.)}

(Yilkal, 2015). In areas of the world where cereal proteins are a major and predominant dietary factor, the associated phytate intake is a cause for concern (Gemede et al., 2014). Fermented roselle seed has least cyanide content $(6.51 \mathrm{mg} / \mathrm{g})$ as compared to other treatments. The values of cyanide $(0.29 \mathrm{mg} / 100 \mathrm{~g})$ obtained by Anhwange et al. (2006) in roselle seed and $0.21 \mathrm{mg} / \mathrm{g}$ to $0.36 \mathrm{mg} / \mathrm{g}$ reported by Abdurrahaman et al. (2017) for nutritional potential of Piliostigma reticulatum $(\mathrm{dc})$ Hotchst pods in semi arid zone of Nigeria were lower than the current values. Generally, only plants that produce more than $20 \mathrm{mg} \mathrm{HCN} / 100 \mathrm{~g}$ fresh weights are considered toxic (Okoli et al., 2003; Njidda, 2010). According to Ramchandra et al. (2017), ruminants are more susceptible to hydro cyanide toxicity than non- ruminants such as horses and pigs. High consumption of feed containing large amount of hydro cyanide usually causes reduced growth; poor feed efficiency and resultant death in large ruminant such as cattle and buffaloes which are more susceptible than small ruminants. The lethal dose of HCN for cattle and sheep is 2.0-4.0 mg per $\mathrm{kg}$ body weight (Kumar et al., 2017). Higher oxalate observed in T2 and T4 indicated that both fermentation and lye water treatment tends to increase the oxalate content of the seed. The oxalate content of the seed $(2.12 \mathrm{mg} / \mathrm{g}$ to $4.36 \mathrm{mg} / \mathrm{g})$ observed in this study were very low when compared with $19.28 \%$ reported by Alwandawi (2015) in roselle seed pod. However, hot water treatment can be considered as the best processing method for reducing the effect of anti-nutritional factors found in the seeds. Oxalates react with calcium to produce insoluble calcium oxalate thereby reducing calcium absorption as well as causing a disturbance in the absorbed calcium: phosphorus ratio (Kumar et al., 2017). The effect of oxalate poisoning in animals varies with species as ruminants adapted to diets with high oxalate content can tolerate oxalate levels that are lethal to non-adapted animals (Ramchandra et al., 2019).

Mineral composition of various processed roselle seed meal

Lye water treatment has significantly increases the $\mathrm{K}$ and $\mathrm{Na}$ contents of the seed, but the values of $\mathrm{K}$ and $\mathrm{Na}$ in this study were lower than $(1329 \pm 1.47 \mathrm{mg} / 100 \mathrm{~g}$ and 659 $\pm 1.58 \mathrm{mg} / 100 \mathrm{~g}$ ) reported by Nzikou, (2011) and $(16.86-20.71 \mathrm{mg} / \mathrm{g}$ and $0.90-2.90 \mathrm{mg} / \mathrm{g}$ ) reported by Sanoussi et al. (2013) for seeds of three Roselle ecotypes from Niger. This variation can be as a result of differences in the geographical location in which the seeds were obtained and the effect of processing methods. The highest value of $\mathrm{Cu}$ was obtained in fermented roselle seed (T2) which was very low compared to $(72 \pm 3.75$ $\mathrm{mg} / \mathrm{g}$ ) revealed by Sanoussi et al. (2013). The Ca contents of the various roselle seeds were also lower than $(4.70 \mathrm{mg} / \mathrm{g}$ to $5.10 \mathrm{mg} / \mathrm{g})$ and $(647 \pm 1.21 \mathrm{mg} / 100 \mathrm{~g})$ reported by Sanoussi et al. (2013) and Nzikou et al. (2011). The values of magnesium obtained in this research were found to be lower than the previous findings made by Nzikou et al. (2011). The zinc contents of the seed were not affected across the treatments, but all the values of zinc were lower than the early findings of previous researchers $(88 \pm 3.88,97 \pm 4.61$ and $75 \pm 2.65 \mu \mathrm{g} / \mathrm{g}$ ) in the seeds of three ecotypes (E3, E7 and E9 respectively) of roselle from Niger (Sanoussi et al., 2013). The values of manganese obtained in the present study increased across the treatments with untreated seed having the least value. Similarly, the values (75 $\pm 2.65 \mu \mathrm{g} / \mathrm{g}$ to $88 \pm 3.88 \mu \mathrm{g} / \mathrm{g}$ ) for Zinc obtained by Sanoussi et al. (2013) were higher than the current values.

\section{Growth performance of grazing of red sokoto bucks}

The final weigh obtained ranged from $13.90 \mathrm{~kg}$ in $\mathrm{T} 1$ to $14.55 \mathrm{~kg}$ in $\mathrm{T} 4$. These values were slightly higher than $11.30 \mathrm{~kg}$ to $13.12 \mathrm{~kg}$ reported by Hassan et al. (2016) in 
hay as a supplement to maize stover basal diet. The fermented roselle seed treatment had the highest weight gain $(3.04 \mathrm{~kg})$ compared to other treatments. These treatments were numerically higher than the control (T1). Also, weight gain in this study was in agreement with the report of previous scientists (Hassan et al., 2016; Makun et al., 2016). However, values obtained by Jibrin et al. (2018) were higher than the current values. The result obtained for feed intake in the current study was lower than the values $(19.82-22.74 \mathrm{~kg})$ obtained by Yashim et al. (2016) from their study on growth performance, nutrient digestibility and nitrogen Balance in red sokoto bucks fed irish potato (solanum tuberosum L.) peels as a replacement for maize offal. The highest FCR (5.91) was recorded from untreated roselle seed (T1), this means that the processing methods have significantly reduced the FCR of the animals. More so, previous researchers (Hassan et al., 2011; Ikyume et al., 2018; Jibril et al., 2018 ) reported higher FCR (3.40-5.91) than obtained in this study.

\section{Conclusion}

The study revealed that processing methods had no effect on the proximate composition of the processed roselle seed, except in the mean values of dry matter and ether extract but substantially reduced the effect of antinutritional factor in roselle seed and can serve as a good source of protein for small ruminant production. It is concluded that supplementation of roselle seed meal in as a diet can successfully improve the performance of goats without any detrimental effect.

\section{Recommendation}

Based on the outcome of this research, hot water treatment is suggested for reducing anti-nutritional factors in seed.

Roselle seed meal either processed or unprocessed can surely be fed to our ruminant animals with a good resultant weight gain as obtained in this study. Further studies may be conducted on feeding diets containing processed roselle seed meal on nutrient digestibility and nitrogen balance to ruminants.

\section{References}

Abdurrahman, S. L., Muhammad, I. R. and Ahmad, M. Y. 2017. Nutritional potential of Piliostigma reticulatum (dc) Hochst pods in semi- arid zone of Nigeria. Nigerian Journal of Animal Production, 44 (4): 287-296.

Akande K. E. and Fabiyi, E. F. 2010. Effect of Processing Methods on Some Anti-nutritional Factors in Legume Seeds for Poultry Feeding. International Journal of Poultry Science 9 (10): 996-1001, 2010, ISSN1682-8356.Akande, K. E., Doma, U. D., Agu, H. O. and Adamu, H. M. 2010. Major Antinutrients Found in Plant Protein Sources: Their Effect on Nutrition. Pakistan Journal of Nutrition, 9 (8): 827-832, 2010, ISSN 1680-5194.

Akande, T. O., Odunsi, A. A. and Adedeji, O. S., 2011. Toxicity and nutritive assessment of castor oil and processed cake in ret diet. Asian Journal of Animal Science, 18 (19).

Al-Wandawi, H. 2015. Organic acids composition of different parts of the medicinal plant-roselle (hibiscus sabdariffa). International Journal of Biological \& Pharmaceutical Research;6(10): 808-813.

Anhwange, B. A., Ajibola, V. O. and Okibe, F. G. 2006. Nutritional value and anti nutritional factors in Hibiscus sabdariffa. Journal of Fisheries International 1 (2-4): 7376.

AOAC 2013. Official methods of analysis (19 ${ }^{\text {th }}$ Edition). Association of 
Nutritional potential and utilization of processed Roselle (Hibiscus sabdariffa L.)

Official Analytical Chemist,

Washington D.C., USA.

Ari, M. M., Ayanwale, B. A., Adama, T. Z., and Olatunji, E. A. 2012a. Effects of Different Fermentation Methods on the Proximate Composition, Amino Acid Profile and Some Antinutritional Factors (ANFs) In Soyabeans (Glycine max) Fermentation Technology and Bioengineering.; 2: 6-13.

Ari, M. M., Ayanwale, B. A., Adama, T. Z., and Olatunji, E. A. 2012b. Effect of Different Fermentation Methods on Growth Indices and Serum Profile of Broiler Chickens. Journal of Biology Agriculture and Healthcare, 25: 78-86.

Avato P., Bucci R, Tava A, Vitali C, Rosato A, Bialy Z, Jurzysta, M. 2006. Antimicrobial activity of saponins from Medicago spp.: Structure-activity relationship. Phytother Res, 20:454-457.

Birendra, K., Niketa, T. and Sanjay, K. 2017. Anti-Nutrient in Fodders: A Review. Chemical Science Review and Letters, 6(24), 2513-2519.

Dupe, O., Ogunbosoye, Tona, G. O. and Otukoya, F. K. 2015. Evaluation of the Nutritive Value of Selected Browse Plant Species in the Southern Guinea Savannah of Nigeria for Feeding to Ruminant Animals. British Journal of Applied Science and Technology, 7 (4): 386395.

Fatoumata, T., Issoufou A., Guo-Wei, L. and Yong-Hui S. 2011. Effect of boiling on the physicochemical properties of Roselle seeds (Hibiscus sabdariffa L.) cultivated in Mali. African Journal of Biotechnology, 10 (79): 1816018166.

Google Earth 2012. Google Location Map; Google Earth Imagery.
Habtamu Fekadu Gemede, Negussie Ratta. Antinutritional Factors in Plant Foods: Potential Health Benefits and Adverse Effects. International Journal of Nutrition and Food Sciences, 3(4): 284-289.

Hassan M. R., Muhammad I. R., Amodu, J. T., Jokthan G. E., Abdu S. B., Adamu H. Y., Yashim S. M., Taofik, I., Tamburawa M. S. and Musa A. 2016. Growth performance of red Sokoto bucks fed graded levels of Lablab (Lablab purpureus) hay as a supplement to maize (Zea mays) Stover basal diet. Journal of National Animal Production Research Institute, 28 (1): 283-298.

Ikyume, T. T., Eigege, N. N., Bashi, D. T., Oche, N. P., Abdulraheem, A. I. and Ojabo, M. 2018. West African dwarf (WAD) goats fed fermented baobab\(Adansonia digitata) seed meal. Journal of Animal Husbandry and Dairy Science 2: 30-36.

Jibrin, T. A., Maigandi, S. A., Makinta, A. A. and Husa. H. 2018 . Performance of Borno White Goat Fed Graded Levels of Alkali Treated Neem Kernel Cake (Atnkc) in a Semi-Arid Zone of Nigeria. Nigerian Journal of Animal Science and Technology, 1 (2):112- 117.

Karma B. R., and Chavan, U. D. 2017. Antioxidant Activity and Nutritional Value of Roselle Seeds Flour. International Journal of Current Microbiology and Applied Science 6 (4): 2654-2663.

Liener, I. E. 2003. Phytohemagglutinins: Their nutritional significance. Journal of Agriculture and Food Chemistry, 22: 17.

Maffo, T. G., Agbor, E. E., Mekoudjou, N. H. S., Kengne S. C. N., Gouado, I. 2014. Proximate and Mineral Composition, Protein Quality of 
Hibiscus Sabdariffa L. (Roselle) Seeds Cultivated in Two Agro Ecological Areas in Cameroon. International Journal of Nutrition and Food Sciences. 3 (4): 251-258.

Makun, H. J., Daudu, O. M., Otaru, S. M., Barje, P. P. and Odegbile, $O$. E. 2016. Effect of Supplementation with different protein sources on the feed intake and growth in red sokoto and sahelian goats. Journal of Animal Production and Research 28(1):263-274.

Mariod, A. A., Suryaputra S., Hanafi M., Rohmana T., Kardono L. B. S., and Herwan T. 2013. Effect of different processing techniques on Indonesian Roselle (Hibiscus radiates) seed constituents. Acta Scientiarum Polonoru Technology Aliment. 12 (4): 359-364.

Njidda, A. A. 2010. Growth performance and nutrients digestibility of weanling rabbits fed graded level of sesame meal (Sesamum indicum) in semi-arid regions of Nigeria. Sahelian Journal of Veterinary Science, 9(1): 1-6.

Nyako, H. D. 2015. Effects of feeding different supplements on the performance of yankasa rams offered a basal diet of cowpea hay in the semi-arid region of Nigeria. Journal of Biology, Agriculture and Healthcare, 1 (6).

Nyam, K. L., Tan, C. P., Lai, O. M., Long, K., Che Man, Y. B. 2009. Some physicochemical properties and bioactive compounds of seed oils. LWT 42: 1396-1403.

Nzikou, J. M., Bouanga-Kalou, G., Matos, L., Ganongo-Po, F. B., and Mboungou-Mboussi, P. S. 2011. Characteristics and Nutritional Evaluation of seed oil from Roselle (Hibiscus sabdariffa L.) in CongoBrazzaville. Current Research
Journal of Biological Sciences, 3(2): 141-146.

Okereke C. N., Iroka F. C., Chukwuma M. O. 2015. Phytochemical analysis and medicinal uses of Hibiscus sabdariffa. International Journal of Herbal Medicine; 2 (6): 16-19.

Okoli, I. C., Anunobi, M. O., Obua, B. E. and Enemuo, V. 2003. Studies on selected browses of Southern Nigeria with particular reference to their proximate and some antinutritional constituents, Livestock Research, For Rural Devevelopment. 15 (9).

Olofin, E. A. 2008. The Physical Settings in (E. A. Olofin, A. B Nabegu, and A. M. Dambazau) Wudil within Kano region: A geographical perspective synthesis. Kano city, Adamu Joji publisher pp.1-34.

Peng, J. P., Yao, X. S., Kobayashi, H. and Ma, C. Y. 1995. Novel Furostanol glycosides from Allium macrostemom. Planta medica,61: 58-61.

Ramchandra R, Raina D and Gendley M. K. 2019. Antinutritional factors in feeds and fodder used for livestock and poultry feeding. Acta scientific nutritional health, 3(5): 39-48.

Sahar, Y. A., Adel, G. A., Shaimaa, E. M., and Mahmoud, E. O. 2017. Roselle Seed as a Potential New Source of Healthy Edible Oil. Journal of biological science, 17:267-277.

Sanoussi, A., Benoît, S., Aissa, B. D., Yacoubou, B., Issaka L. and Mahamane, S. 2013. Nutrients composition of calyces and seeds of three Roselle (Hibiscus sabdariffa L.) ecotypes from Niger. African Journal of Biotechnology, 12 (26): 4174-4178.

SAS, 2013. SAS user's guide. Statistics. SAS Institute, Cary, North Carolina, USA. 


\section{Nutritional potential and utilization of processed Roselle (Hibiscus sabdariffa L.)}

Smitha, P. A., Alagundagi, S. C. and Salakinkop, S. R. 2013. The antinutritional factors in forages - A review. Current Biotica 6(4): 516526, 2013, ISSN 0973-4031.

Stewart, E. 1974. Chemical analysis of ecological material. Black scientific publication, Oxford, UK., pp: 298312.

Uguru, C. 2014. Nutritional potential of acacia (Acacia nilotica) pods for growing red Sokoto goats. A dissertation submitted to the post graduate school of Ahmadu Bello University, Zaria.

Yacout, M. H. M. 2016. Antinutritional factors and its roles in animal nutrition. Journal of dairy, veterinary and animal research, 4(1):237-239.

Yashim, S. M., Haniel, B., Makama, S. R. and Adamu, H. Y. 2016. Growth performance, nutrient digestibility and nitrogen Balance of red sokoto bucks fed irish potato (solanum tuberosum L.) Peels as a replacement for maize offal. Journal of Animal Production and Research, 28(1):245-253.

Yilkal, T. 2015. Important Anti-Nutritional Substances and Inherent Toxicants of Feeds. Journal of Food Science and Quality Management, vol 36. ISSN 2224-6088 (Paper) ISSN 2225-0557 (Online).

Received: $16^{\text {th }}$ September, 2020

Accepted: $28^{\text {th }}$ January, 2021 